\title{
Cr-Fe-Y (Chromium-Iron-Yttrium)
}

\section{Raghavan}

The study of this ternary system by [1959Far] was reviewed by [1992Rag], who presented two tentative isothermal sections at $\sim 1240$ and $600{ }^{\circ} \mathrm{C}$. Recently, $[2010 \mathrm{He}]$ reinvestigated this system at $500{ }^{\circ} \mathrm{C}$ and confirmed the presence of a previously-reported ternary compound $(\mathrm{Fe}, \mathrm{Cr})_{12} \mathrm{Y}$.

\section{Binary Systems}

In the $\mathrm{Fe}-\mathrm{Cr}$ phase diagram, a gamma loop restricts the fcc region to about 12 at.\% $\mathrm{Cr}$. The bcc $\alpha$ phase is stable over a large region. The intermediate phase $\sigma\left(D 8_{b}\right.$-type

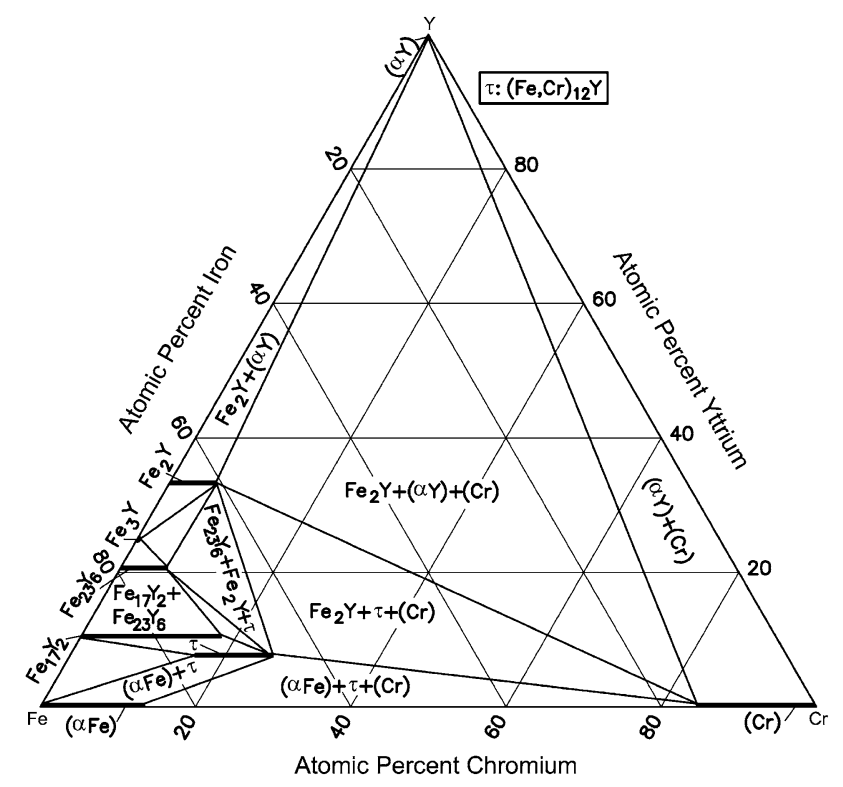

Fig. $1 \mathrm{Cr}-\mathrm{Fe}-\mathrm{Y}$ isothermal section at $500{ }^{\circ} \mathrm{C}[2010 \mathrm{He}]$. Narrow two-phase regions are omitted tetragonal) forms from $\alpha$ at $820^{\circ} \mathrm{C}$ around the midcomposition and decomposes eutectoidally at $545{ }^{\circ} \mathrm{C}$ to Fe-rich bcc $(\alpha)$ and Cr-rich bcc $\left(\alpha^{\prime}\right)$ phases. The Fe-Y system is characterized by the presence of four compounds: $\mathrm{Fe}_{2} \mathrm{Y}\left(\mathrm{C} 15, \mathrm{MgCu}_{2}\right.$-type cubic), $\mathrm{Fe}_{3} \mathrm{Y}\left(\mathrm{Be}_{3} \mathrm{Nb}\right.$-type rhombohedral), $\mathrm{Fe}_{23} \mathrm{Y}_{6}\left(D 8_{a}, \mathrm{Mn}_{23} \mathrm{Th}_{6}\right.$-type cubic) and $\mathrm{Fe}_{17} \mathrm{Y}_{2}$ $\left(\mathrm{Ni}_{17} \mathrm{Th}_{2}\right.$-type hexagonal or $\mathrm{Th}_{2} \mathrm{Zn}_{17}$-type rhombohedral). The Cr-Y system is of the simple eutectic type with no intermediate phases.

\section{Ternary Isothermal Section}

With starting metals of $99.9 \% \mathrm{Cr}, 99.99 \% \mathrm{Fe}$ and $99.9 \%$ $\mathrm{Y},[2010 \mathrm{He}]$ arc-melted under Ar atm 188 alloys. The alloys were given a final anneal at $500{ }^{\circ} \mathrm{C}$ for 10 days and quenched in liquid nitrogen. The phase equilibria were studied with x-ray powder diffraction, differential thermal analysis, and scanning electron microscopy equipped with energy dispersive $\mathrm{x}$-ray spectroscopy.

The isothermal section constructed by $[2010 \mathrm{He}]$ is shown in Fig. 1. The previously-reported compound $\mathrm{YFe}_{12-x} \mathrm{Cr}_{x}(x=2.1-3.4)$ ( $\mathrm{ThMn}_{12}$-type tetragonal) is present. The other known compound $\mathrm{Y}_{3}(\mathrm{Fe}, \mathrm{Cr})_{29}$ was not found at $500{ }^{\circ} \mathrm{C}[2010 \mathrm{He}]$. The binary compounds $\mathrm{Fe}_{17} \mathrm{Y}_{2}, \mathrm{Fe}_{23} \mathrm{Y}_{6}$ and $\mathrm{Fe}_{2} \mathrm{Y}$ dissolve up to 18,6 and 6 at.\% $\mathrm{Cr}$ respectively.

\section{References}

1959Far: M.S. Farkas and A.A. Bauer, The Solid Solubility and the Constitution of $\mathrm{Y}$ in $\mathrm{Fe} / 20-40$ mass\% Cr Alloys, U.S. Atomic Energy Comm. Publ., BMI-1386, 1959, p 1-20

1992Rag: V. Raghavan, The $\mathrm{Cr}-\mathrm{Fe}-\mathrm{Y}$ (Chromium-Iron-Yttrium) System, Phase Diagrams of Ternary Iron Alloys. Part 6B, Ind. Inst. Metals, Calcutta, 1992, p 707-710

2010He: W. He, X. Wang, J. He, J. Wen, M. Yu, and L. Zeng, Isothermal Section of the Y-Fe-Cr Ternary System at $773 \mathrm{~K}$, J. Alloys Compd., 2010, 502, p 87-91 